\title{
BASIC ELECTROTECHNOLOGY
}




\section{BASIC \\ ELECTROTECHNOLOGY}

H. COTTON, D.Sc.

Emeritus Professor of Electrical Engineering

University of Nottingham 
(C) H. Cotton 1973

All rights reserved. No part of this publication may be reproduced or transmitted, in any form or by any means, without permission

First published 1973 by

THE MACMILLAN PRESS LTD

London and Basingstoke

Associated companies in New York

Dublin Melbourne Johannesburg and Madras

SBN 333143116

ISBN 978-0-333-14311-7 ISBN 978-1-349-01705-8 (eBook)

DOI 10.1007/978-1-349-01705-8 


\section{PREFACE}

Unlike a treatise, which is a statement of original work undertaken to increase knowledge, whether that knowledge can be applied to human problems or not, a text-book is a collection of material already known.

The justification for an additional text-book to the vast number already in existence is therefore dependent on (a) the choice of material and its suitability to some specific purpose, and (b) the clarity of the exposition; is it such that the book can be understood by students of average ability?

The present book satisfies requirement (a) because it is written for a specific purpose, namely, to cover the syllabus of the subject of Electrical Principles II of the City and Guilds of London Institute. As far as requirement (b) is concerned it is hoped that the author's long experience of technical writing has ensured that this also is satisfied.

Where it seemed advantageous the requirements of the syllabus have been exceeded in a few cases, for example, a discussion of the present-day importance of the metal sodium as a conductor of electricity, and a description of the mercury cell.

The book ends with a collection of exercises, and since it is probable that the so-called Imperial system of units will survive for a few years the data for a few of the exercises corresponds to this system.

As this is a new book there may be suggestions, or even criticisms, from readers. The author will be grateful for such co-operation.

Woodbridge,

H. Cotton Suffolk 


\section{CONTENTS}

1 The SI System of Units 1

2 Electricity 13

3 Potential 23

4 The Electric Current 32

5 Power, Energy, Heat 42

6 Electric Circuits 51

7 Electrical Resistance $\quad 59$

8 Magnetism $\quad 69$

9 The Magnetic Fields Produced by Electric Currents 82

10 The Magnetic Circuit 94

11 Induced e.m.f. 109

12 Capacitors and Insulating Materials 124

13 Chemical Effects 139

14 Alternating Currents 159

15 Three-phase Working and Rotating Magnetic Fields 190

16 The Transformer 197

17 Electric Machines $\quad 214$

18 Electronic Devices 240

19 Electrical Measuring Instruments 267

Exercises $\quad 287$

Index $\quad 307$ 